Research, part of a Special Feature on The influence of human demography and agriculture on natural systems in the Neotropics

\title{
Thirty Years of Human Demography and Land-Use Change in the Atlantic Forest of Misiones, Argentina: an Evaluation of the Forest Transition Model
}

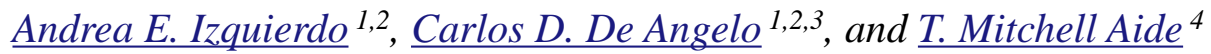

\begin{abstract}
For many years, tropical and subtropical forests have been deforested for agriculture, grazing, and timber extraction. Nevertheless in the last decade, several publications have suggested that some regions of Latin America are showing a process of forest transition. Forest transition theory predicts that industrialization and urbanization will lead to the abandonment of marginal agriculture lands and the recovery of natural systems such as forests. However, there are many ecological, economic, and social factors that could act as barriers to ecosystem recovery. To evaluate this hypothesis, we analyzed the socioeconomic and land-use changes during the last 30 years at the provincial and departmental level in the province of Misiones, Argentina. We described the changes in the distribution of urban and rural populations based on national population censuses from 1970, 1980, 1991, and 2001. Land-use change was based on a supervised analysis of four mosaics of Landsat Multispectral Scanner and Thematic Mapper satellite images from 1973, 1979, 1987/1989, and 2006. Although the change in the rural population varied greatly among the departments, there has been a dramatic increase in the urban population at the provincial level. The major land-use changes between 1973 and 2006 were an increase in monospecific plantations of mainly Pinus and Eucalyptus of $2702 \mathrm{~km}^{2}$ and a loss of $4689 \mathrm{~km}^{2}$ of natural forest. Misiones possesses the largest remnant of continuous Atlantic Forest, which is famous for its high level of biodiversity and endemism, but much of this forest now comprises monospecific plantations. Although demographic changes in Misiones are similar to those that have occurred other regions (i.e., rural-urban migration), and the increase in forest plantations helps to maintain forest cover, this cover has much lower ecological value than that of natural forest. To ensure the conservation of the high-diversity Atlantic Forest in Misiones requires a better effort to understand the interactions among the diverse factors that affect land-use patterns in this region.
\end{abstract}

Key Words: Atlantic Forest; forest plantations; forest transition; rural-urban migration

\section{INTRODUCTION}

Ever since Malthus in 1798 introduced the relationship between human population growth and agricultural development, or more generally the environment, it has created much controversy (e.g., Boserup 1965, Pimentel et al. 1998). Today, however, few would deny that humans have had an enormous impact on the environment, particularly given that we have transformed between 30 and $50 \%$ of terrestrial ecosystems for our direct or indirect use (Dobson et al. 1997, Vitousek et al. 1997, Sanderson et al. 2002). Furthermore, the world's population and per capita calorie consumption continue to grow; thus, the impact on natural systems is also expected to increase. However, population growth is slowing (Lutz et al. 2001), and the population is shifting from mainly rural to urban. These factors could reduce the direct impact of humans on natural areas (Aide and Grau 2004, Wright and Muller-Landau 2006).

The magnitude of rural-urban migration and the success of migrants and their descendents in urban centers are some of the many interacting factors that will affect global land-use change. The huge 
migration of rural Chinese, mainly to factory jobs in coastal cities (Fan 2005), has been a major contribution to the global urban population, accounting for $>50 \%$ of the population in 2007 (United Nations Population Fund 2007). However, rural-urban migration is not restricted to China; the rural population of South America declined by $>5$ million people between 1990 and 2000 (Food and Agriculture Organization FAOSTAT: http://faostat. fao.org/site/550/DesktopDefault.aspx?PageID $=550$ ), and this trend is predicted to continue throughout most of the developing world (International Organization for Migration 2004). In Latin America, some of the major drivers of rural-urban migration have been the intensification of agriculture in the most productive soils, increasing job opportunities in urban areas, and the internationalization of job markets (Preston 1996). Will the reduction in rural population density caused by rural-urban migration decrease the pressure on natural areas (Aide and Grau 2004, Wright and Muller-Landau 2006) or will increasing food consumption and new demands for biofuels erase any positive effects of rural-urban migration?

Rural-urban migration is frequently identified as one of the most important drivers of forest transition. Forest transition theory predicts that as societies undergo economic development, industrialization, and urbanization, forest cover will increase (Mather and Needle 1998). This theory has been supported by evidence from $>50$ countries, mainly developed, in which forest cover increased between 1990 and 2000 (Waggoner and Ausubel 2001). The process of forest transition has also been reported for some developing countries in Latin America, including Puerto Rico (Grau et al. 2003, Parés-Ramos et al. 2008), Dominican Republic (Grau et al. 2007b), Ecuador (Rudel et al. 2002), Honduras (Southworth and Tucker 2001), and many mountainous regions throughout Latin America (e.g., Zweifler et al. 1994, Klooster 2003, Grau and Aide 2007, Grau et al. 2007a). Although rural-urban migration is an important component in these examples, it alone does not guarantee the spontaneous regeneration of natural forest because other ecological, economic, and social factors can act as barriers to ecosystem recovery and lead to other outcomes of forest transition (Rudel et al. 2005). For example, in areas with fertile soils, rural-urban migration could be the result of agricultural modernization, i.e., a decrease in farm labor, and there would be no increase in forest cover, but rather an increase in large-scale modern agriculture. In other cases, new forests are dominated by exotic species or plantations, and although this does little to conserve biodiversity, it can improve many ecosystem services such as carbon sequestration and soil and water conservation (Rudel et al. 2005).

Our aim was to understand the complex relationships between patterns of human demographics, specifically rural-urban migration, and land use in Misiones, Argentina. Misiones contains one of the largest remaining areas of Atlantic Forest, but it has experienced rapid population growth and extensive deforestation during the last 40 years (Galindo-Leal and Gusmão Câmara 2003). Although the conversion of these high-diversity forests to other uses in Misiones has not been as extreme as in Brazil and Paraguay, if government policies continue to promote the expansion of plantations, agriculture, and cattle ranching, the distribution of Atlantic Forest will continue to decline (Galindo-Leal and Gusmão Câmara 2003). By better understanding the interactions among socioeconomic factors and landuse dynamics and incorporating this information into land-use policy and conservation agendas, continuing economic development in Misiones should be possible without further affecting natural forest cover. Specifically, we describe the trends in land-use and demographic dynamics during the last 30 years at the province and department levels. In addition, we evaluate the forest transition hypothesis by documenting the trends in land-use change between 1989 and 2006 following a decline in the rural population.

\section{METHODS}

\section{Study area}

This study was conducted in the province of Misiones $\left(29,801 \mathrm{~km}^{2}\right)$, northeast Argentina (Fig. 1). Misiones is divided into 17 departments. The department is the smallest administrative unit for which there are reliable demographic data.

Misiones possesses the largest remaining area of continuous Atlantic Forest $\left(\sim 1.0 \times 10^{4} \mathrm{~km}^{2}\right)$. This region is one of Conservation International's Hotspots and one of the World Wildlife Fund's Global 200 and is characterized by high levels of biodiversity and endemic species (Myers et al. 2000). This forest type also occurs in southern Brazil and eastern Paraguay, although it is highly fragmented and occupies $<6 \%$ of the original cover, 
Fig. 1. Location of the province of Misiones, Argentina, in South America (inset), and the distribution of the 17 departments within the province.

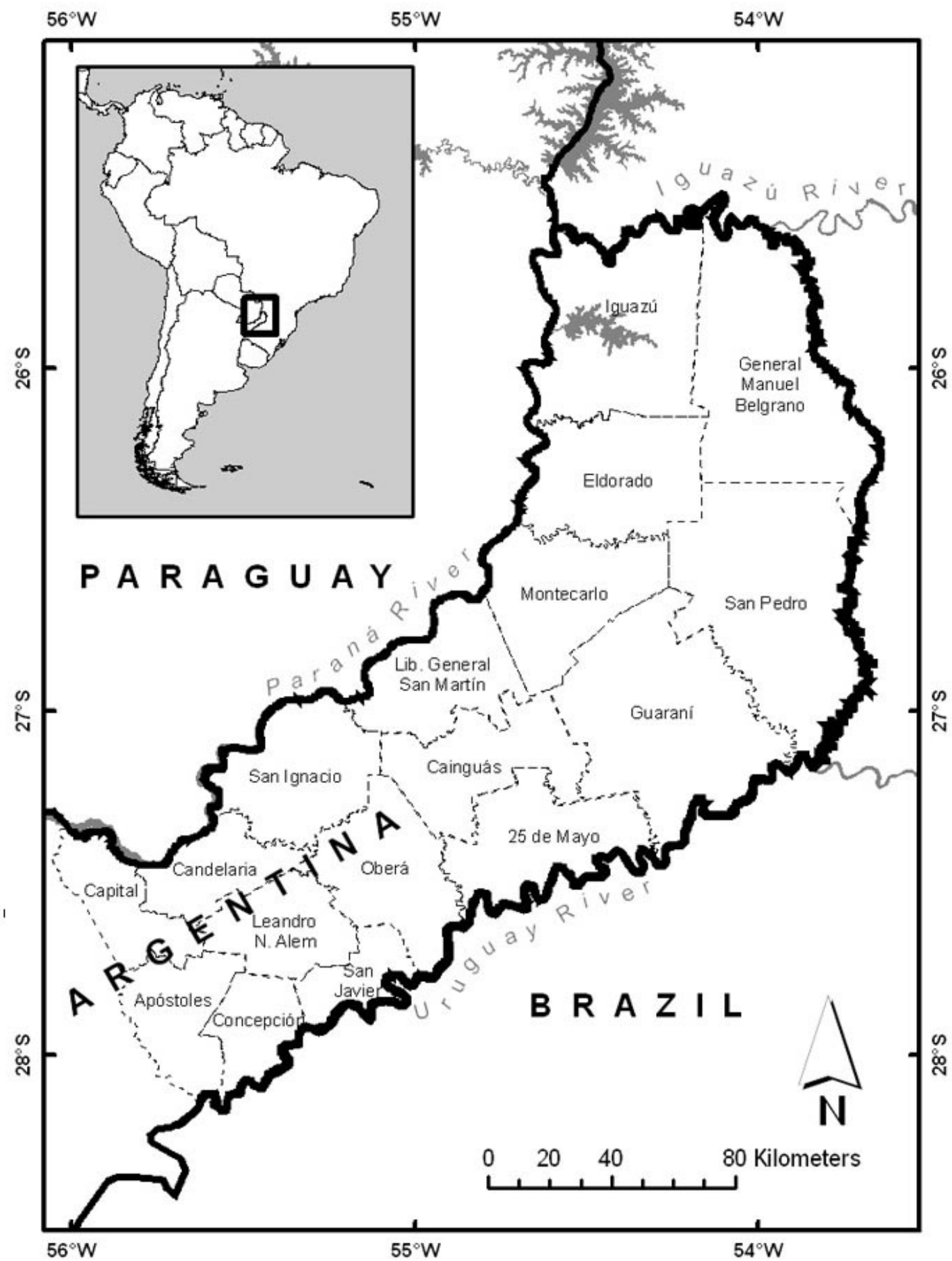


mainly because of conversion to agriculture (Galindo-Leal and Gusmão Câmara 2003).

The territory that now includes the province of Misiones has been inhabited by the Guarani for > 6000 yr (Martínez Sarasola 1992), but the population was small until the Jesuit priests entered the region in the 17th century. By the middle of the 18th century, Misiones had 46,500 inhabitants and was the region with the largest population in Argentina (Instituto Nacional de Estadísticas y Censos 1980). During the 18th century, the population declined because the Jesuit priests were expelled and there were many wars in the region. In 1881, the federal government implemented a colonization program to promote agriculture in the region and divided the province into 27 properties that were sold to a few individuals (Belasteguí 2004). In the early 1900s, colonization proceeded mainly from the south to the north in two waves. The first wave of colonization occurred on public lands mainly in the departments in the southwest and the central plateau. The second wave settled mainly on private lands in the Parana River valley, which is the western boundary of the province (Belasteguí 2004). During the 1980s, the government promoted a new wave of colonization in the northeastern departments of Misiones to establish a presence along the Brazilian border (Schiavoni 1995). In this program, migrants were given land and were required to deforest at least $50 \%$ of that land to maintain ownership (Schiavoni 1995).

\section{Population and land-use data}

Spatial and temporal changes in the distribution of the population in urban and rural areas of Misiones were described by analyzing data from the last four national population censuses (Instituto Nacional de Estadísticas y Censos 1970, 1980, 1991, 2001). In Argentina, the censuses are universal and are made by direct interview. The population censuses collect information on demographic and social aspects of all inhabitants. Rural and urban populations are divided by the threshold of 2000 inhabitants per locality.

The changes in the land-use patterns in Misiones were described by analyzing satellite images from 1973, 1979 (Landsat Multispectral Scanner [MSS], $80 \times 80$ pixel resolution), 1987, 1989, and 2006 (Landsat Thematic Mapper [TM], $30 \times 30$ pixel resolution). Four images cover the province of Misiones: paths 223 and 224, rows 78 and 79 of Landsat TM; and paths 239 and 240, rows 78 and 79 of Lansdsat MSS. To construct cloud-free mosaics for each date, we used the following scenes: (1) 1973: February 1973 (240/78, 240/79) and March 1973 (239/78, 239/79); (2) 1979: September $1979(240 / 78,240 / 79)$ and November 1979 (239/78, 239/79); (3) 1987/1989: March 1987 (223/79, 223/78), April 1989 (224/78), and May 1989 (224/79); and (4) 2006: July 2006 (224/78, 224/79) and August 2006 (223/78, 223/79).

We used a geo-referenced Misiones Government mosaic from 1999 (Argentine Transverse Mercator National Projection Zone 7) as a base image to coregister all images for the analysis. We used the nearest-neighbor resampling method for coregistration. The co-registration error was $<0.3$ pixels. All images were sub-set with the provincial boundaries. We used images from different dates to create cloud-free mosaics, but these images had different spectral properties because of differences in the atmosphere and vegetation phenology. To correct for this problem, we characterized the spectral signatures of each land-use class (i.e., assigned training sites) for each of the four images for each year. This is an alternative approach for radiometric correction that has been validated by Song et al. (2001).

For the supervised classification, we used the maximum likelihood method to identify specific areas of various land-use categories that did not change during the study period. In addition, we used a detailed land-use map of the Andresito region for 2002 (Guerrero Borgues 2004) to identify areas of various land-use categories that had been verified. Using these sites as references, we selected and digitized training sites distributed across the province of Misiones for the supervised classification. Training sites were selected for each image for each year. To capture the variation in forests and plantations, we initially assigned training sites for various subclasses of forest, i.e., forest, riparian forest, forest on slopes with shadows, forest on ridge tops with high reflectance, and for various subclasses of plantation, i.e., recently planted plantations, young plantations, and mature plantations. After the initial classification, each scene was post processed. The sieve function was used to set the group minimum threshold at four pixels for all classes except urban (80 pixels). The clump function was set at $3 \times 3$ pixels. The forest 
and plantation subclasses were then combined into the forest and plantation classes, resulting in a total of 10 land-use classes (Fig. 2, Table 1). For the final post processing, we set the sieve and clump functions at 40 pixels and $3 \times 3$ pixels, respectively, for the forest and plantation classes.

Given the time span of the study (33 yr) and the spatial scale $\left(2.9 \times 10^{6} \mathrm{ha}\right)$, it was not possible to assess the accuracy for all years using an alternative method such as aerial photography. Instead, we assessed the accuracy of the 2006 land-use map using Quickbird satellite images (2.4-m resolution, 2003-2006) available through GoogleEarth (http:// earth.google.com/). In regions of Misiones covered by Quickbird images, we constructed a $5-\mathrm{km}$ grid of points. At each intersection, we determined the land-use category. A total of 370 points were sampled. To increase the cover of less common land-use categories such as pasture and urban, we supplemented the grid points with additional points until we had approximately 100 points for each landuse category, for a total of 704 points. These control points were compared with the 2006 land-use map, and the overall accuracy was $84 \%$ (Table 2). Over $80 \%$ of forest, plantation, campos (native grassland), and urban classes were classified correctly, and between 70 and $80 \%$ of the pasture, mixed (i.e., subsistence agriculture), and agriculture classes were classified correctly (Table 2). An explanation for the lower accuracy for the latter groups could be the difference in the resolution between the Quickbird and Landsat images, which can affect the classification of uses that occur in small areas and in landscapes with high levels of heterogeneity. Another explanation for the misclassification of some land-use types may be that they have similar spectral properties during certain times of the year. However, in all cases, the level of separability (transformed divergence: $>1.50$ ) was sufficient to differentiate classes in the supervised classification. Given that we used the same methodology for all years, we expect that the level of accuracy measured for the 2006 classification should be similar for the other years.

We described the patterns of land-use change in Misiones for the four periods: 1973, 1979, 1987/1989, and 2006. Population data were analyzed for the period of 1970 to 2001. Specifically, we evaluated the change in the rural population at the level of the province. The rural population began to decline slightly following the 1991 census, but the pattern varied greatly among the 17 departments. To evaluate the forest transition hypothesis, we determined the change in the rural population for each of the departments for the period of 1991 to 2001 and compared vegetation cover, including forest and plantation, and natural forest cover in each department for the period of 1989 to 2006. We compared the changes in land use for a period that extended past the last demographic census because we expected a time lag between rural population decline (i.e., land-use abandonment) and vegetation response.

\section{RESULTS}

\section{Population dynamics}

Between 1971 and 2001, the population of Misiones increased by $>5.0 \times 10^{5}$ people, but virtually all of the growth was in the urban population (Fig. 3A). Between 1970 and 1991, the rural population increased by 8426 people (3\%); however, between 1991 and 2001 the rural population lost 10,024 people $(3.4 \%)$. The change in the rural population varied greatly among the departments (Fig. 3B). Between 1991 and 2001, the rural population increased in seven departments and decreased in ten departments. The departments representing the extremes were Guaraní, where the rural population increased by 7304 inhabitants, and San Ignacio, which lost 6735 rural inhabitants.

\section{Land-use change}

Between 1973 and 2006, $4689 \mathrm{~km}^{2}$ of natural forest cover was converted to other uses, representing a decrease from 65 to $49 \%$ forest cover for the whole province (Fig. 4). During the same period, the area dedicated to forest plantations increased by 2702 $\mathrm{km}^{2}$, representing an increase from 1 to $\sim 10 \%$ of the province (Fig. 4). This increment was mainly exotic pine and Eucalyptus plantations, and to a lesser extent, plantations of the native Araucaria angustifolia. The area dedicated to agriculture increased by $1740 \mathrm{~km}^{2}$ between 1979 and 1987/1989 (Fig. 4). Areas that were classified as mixed use declined by $551 \mathrm{~km}^{2}$ during the whole study period, but there was a large increase in 1979 (Fig. 4). In general, areas that were classified as pasture increased during the study period, whereas areas that were classified as campos declined (Fig. 4). Although urban area increased throughout the 
Fig. 2. The 2006 classification map of Misiones, with examples of the different land-use categories.

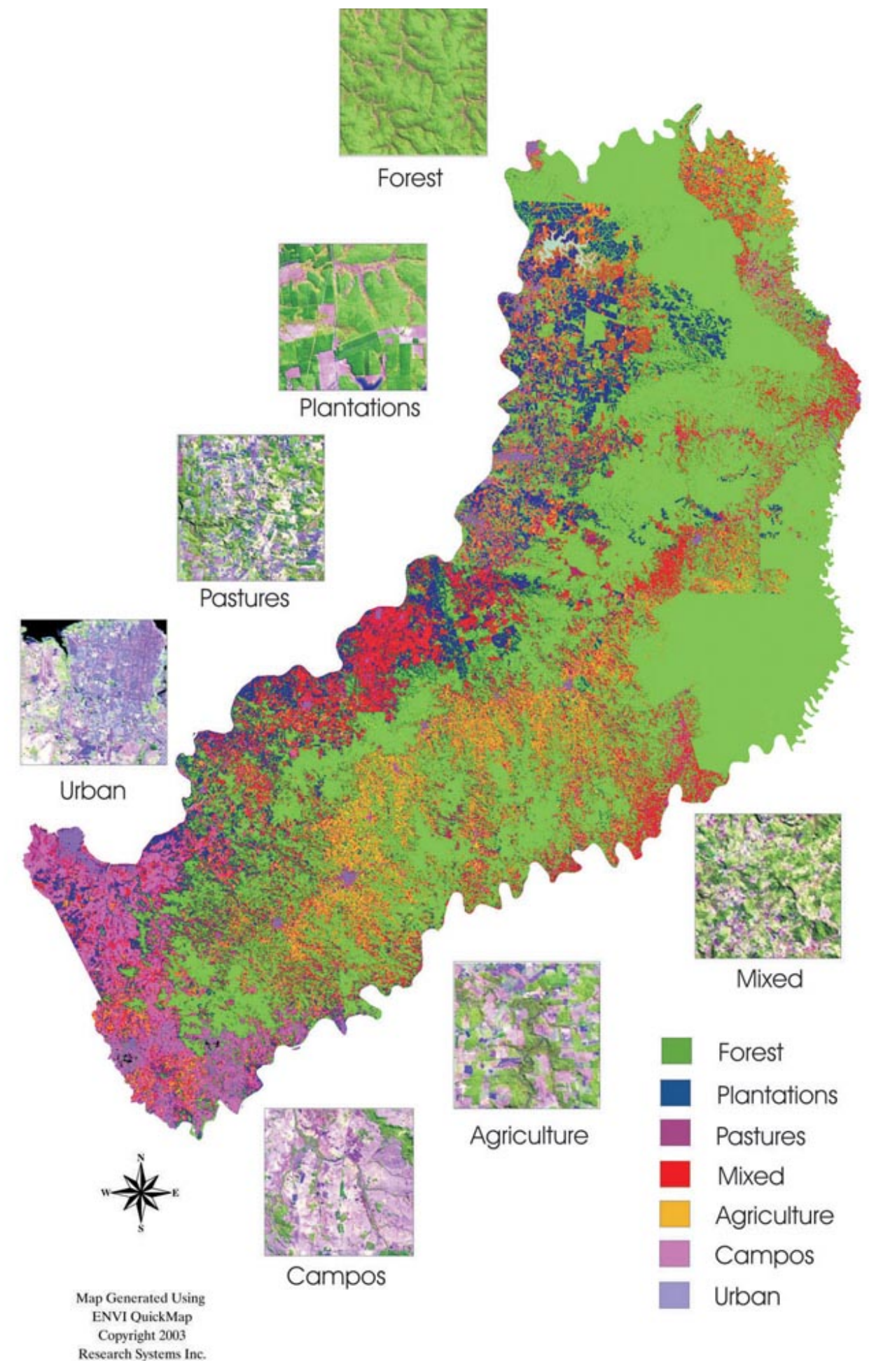


Table 1. Descriptions of the land-cover classes used for satellite image classification.

\begin{tabular}{|c|c|}
\hline Land-cover class & Definition \\
\hline Water $\dagger$ & Lakes, lagoons, dams, or large rivers \\
\hline Forest & $\begin{array}{l}\text { Natural forest, including old-growth forest, secondary forest, and riparian forest; protected } \\
\text { areas were included in this land-cover class }\end{array}$ \\
\hline Plantation & $\begin{array}{l}\text { Monospecific stands of Pinus, Eucalyptus, and Araucaria that are used for lumber and pulp } \\
\text { production }\end{array}$ \\
\hline Cleared $\dagger$ & Bare ground; usually associated with agriculture, plantations, and/or mixed agriculture \\
\hline Agriculture & Areas dominated by perennial crops of tea and yerba mate \\
\hline Mixed use & Areas of subsistence agriculture often mixed with small pastures and shrubland \\
\hline Pasture & $\begin{array}{l}\text { Grassland that was established over the last } 100 \text { years in what was forested habitat; these } \\
\text { areas are usually dominated by African grasses. }\end{array}$ \\
\hline Campos & $\begin{array}{l}\text { Native grassland or areas that were converted to grassland }>100 \mathrm{yr} \text { ago; these areas are } \\
\text { dominated by native grass species and occur mainly in the southern part of the province }\end{array}$ \\
\hline Urban & Cities, roads, and other built-up areas \\
\hline Unclassified & Pixels that could not be confidently assigned to a land-cover class \\
\hline
\end{tabular}

$\dagger$ These classes are considered as "other" in most of the analyses, figures, and tables.

study period, by 2006 it occupied only $1 \%$ of the province (Fig. 4).

The matrix of land-use changes between 1989 and 2006 shows that the largest change at the provincial level was the conversion of natural forest cover to mixed use $\left(1204 \mathrm{~km}^{2}\right)$, plantation $\left(1086 \mathrm{~km}^{2}\right)$, and agriculture (1008 $\mathrm{km}^{2}$; Table 3$)$. In contrast, the largest source of new forest in 2006 was areas that were in mixed use in 1989 (Table 3).

\section{Forest transition}

Forest transition theory predicts that rural-urban migration should lead to the abandonment of marginal areas, e.g., subsistence agriculture. We found a positive relationship between the change in the rural population and the change in mixed cover
$\left(R^{2}=0.29, P<0.05\right.$; Fig. 5). Departments such as Cainguas and Obera that lost rural population experienced a decrease in the area of the mixed cover land use, whereas the rural population of Guarani increased by $>7000$ people and the area of mixed cover increased by $>205 \mathrm{~km}^{2}$. Although there was a positive relationship, there were exceptions: five departments lost rural population, but the area of mixed cover increased; and three departments gained rural population, but the area of mixed cover decreased.

Did rural decline and a decrease in mixed land use result in forest transition? There was a significant negative relationship $\left(R^{2}=0.47, P<0.05\right)$ between the change in the rural population and the change in forest cover (forest and/or plantation; Fig. 6A). The departments that had the largest increase in rural population, i.e., Guarani, San Pedro, and Gral M. Belgrano, were those that lost the greatest area in 
Table 2. Assessment of the accuracy of the land-use classification for 2006 by verification using Quickbird images from GoogleEarth.

\begin{tabular}{lccccccc}
\hline \hline \multirow{2}{*}{ Image classification } & \multicolumn{7}{c}{ Quickbird image } \\
\cline { 2 - 8 } & Forest & Plantation & Agriculture & Mixed & Pasture & Campos & Urban \\
\hline Forest & 118 & 4 & 2 & 4 & 4 & 2 & - \\
Plantation & 6 & 97 & 2 & 3 & 3 & 4 & - \\
Agriculture & 1 & 3 & 78 & 10 & 3 & 3 & 2 \\
Mixed & - & 1 & 7 & 73 & 6 & 1 & - \\
Pasture & - & 1 & 5 & 8 & 62 & 9 & 1 \\
Campos & 1 & - & 3 & 1 & - & 78 & 1 \\
Urban & 1 & - & - & 5 & 3 & - & 79 \\
Other & 1 & 0 & 1 & 0 & 3 & 0 & 0 \\
Total & 128 & 106 & 98 & 104 & 84 & 97 & 83 \\
Accuracy (\%) & 92.2 & 91.5 & 79.6 & 70.2 & 73.8 & 80.4 & 95.2 \\
Total accuracy & & & & 83.6 & & & \\
$(\%)$ & & & & & & & \\
\hline
\end{tabular}

forest and/or plantation cover and are located in the northeastern region of the province along the Brazilian border (Fig. 1). Five departments that had decreasing rural populations, i.e., Apostoles, Oberá, Concepción, Capital, and San Javier, gained forest and/or plantation cover. These departments are all located in the southern part of the province, and their rural populations have been decreasing since 1970 . Although these results support the predictions of the forest transition hypothesis, other departments that also lost rural population had a decrease in forest and/or plantation cover. This pattern of loss of rural population and a decrease or minimal increase in forest and/or plantation cover is more obvious when only forest cover is analyzed $\left(R^{2}=0.51, P<0.05\right.$; Fig. 6B). Again, there was only a minimal increase in forest cover in just a few of the southern departments.

\section{DISCUSSION}

Between 1970 and 2001, the major demographic change in Misiones was a doubling of the population, with virtually all of the growth in the urban centers (Fig. 2). Another important change was the decrease in the rural population during the 1990 s, but this change varied greatly among the departments. Most of the southwestern, central, and northwestern departments lost rural population, whereas the northeastern departments gained rural population. These differences are related to the colonization history of the province. The first European settlers mainly colonized the southern and central region, where the major economic activity was the production of yerba mate, and the northwestern region, where the major activity was timber extraction (Schiavoni 1995, Belasteguí 2004). During the 1970s, government credit and subsides promoted the establishment of pulp and paper companies, mainly in these departments 
Fig. 3. (A) Change in rural and urban populations at the province scale. (B) The relationship between the change in the rural population between 1991 and 2001 and the rural population in 1991 for each department.
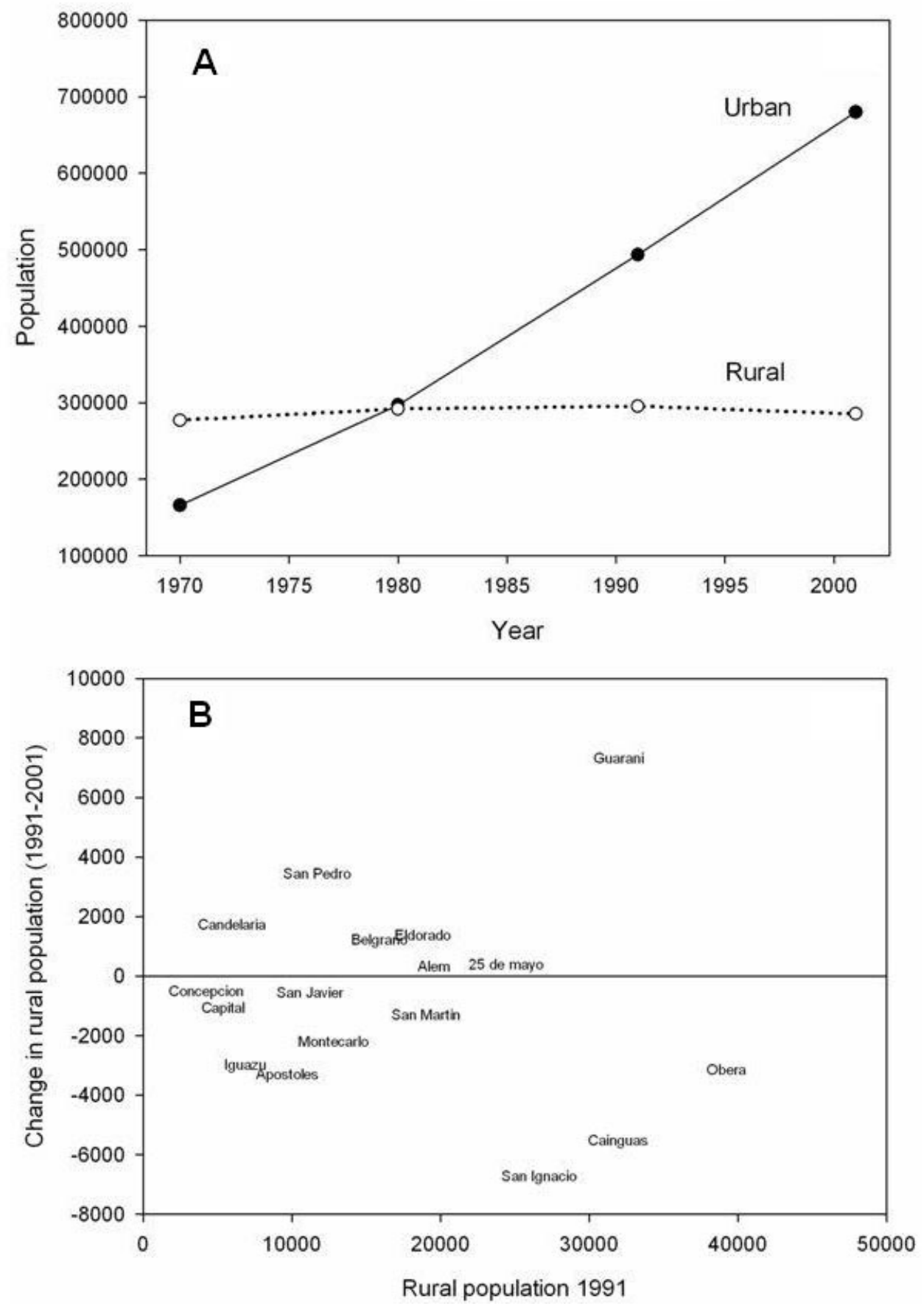
Fig. 4. Change in land-use categories at the provincial level for 1973, 1979, 1987/1989, and 2006.

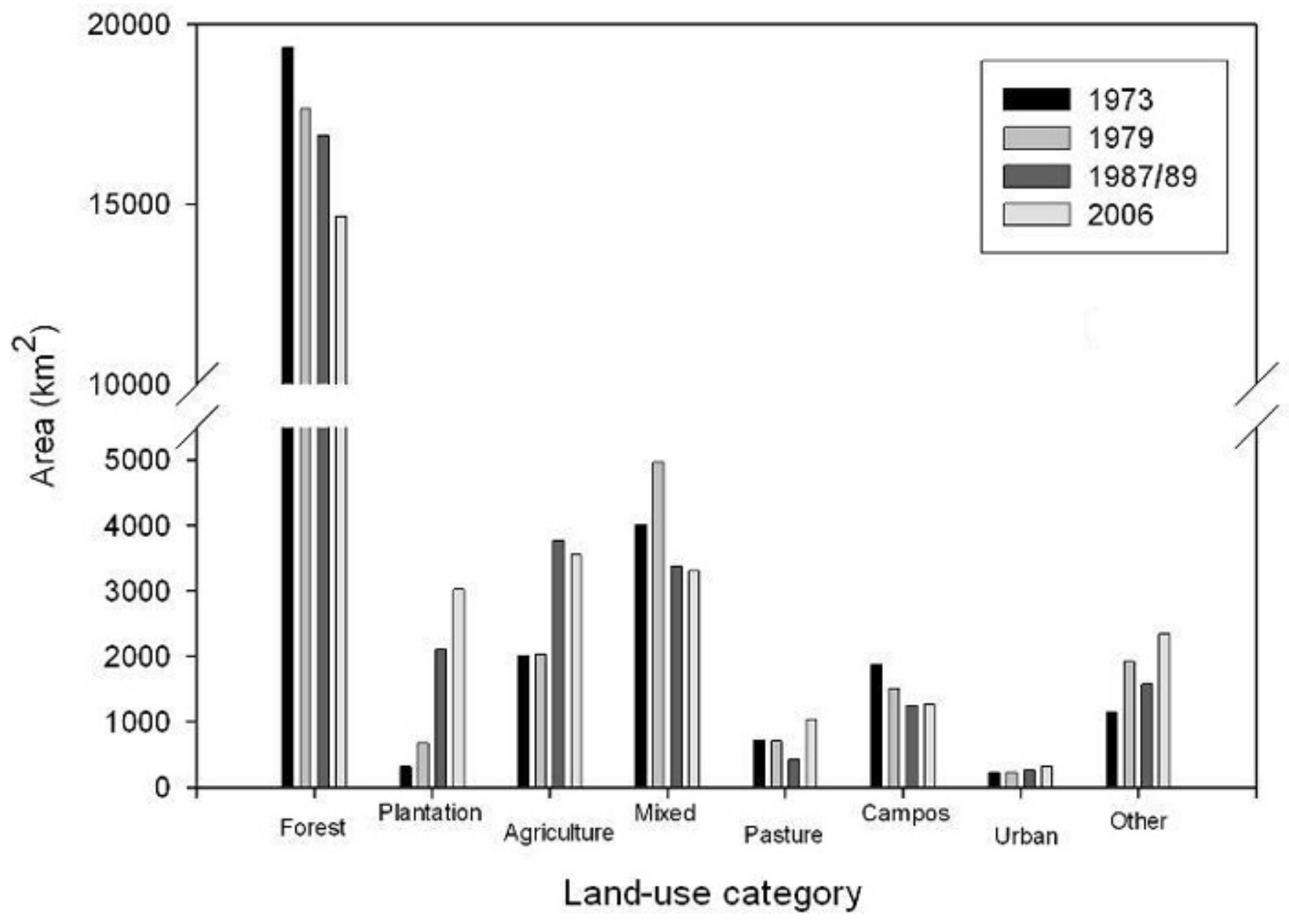

(Laclau 1994). Although the economy of this region of Misiones was based mainly on agriculture and forest products, these departments all have developed urban centers, e.g., Posadas, the provincial capital, with a population of 255,052 and Oberá with a population of 55,493 in 2001 . The demographic dynamics of the northeastern departments have mainly been driven by the colonization of these areas in the 1980s and the associated increase in the rural population and forest transformation mainly to subsistence agriculture. In addition, the rural population of these departments has increased because of the immigration of illegal Brazilian subsistence farmers.

Although the rural population of the province has declined, the continued loss of forest cover, even when plantations are included as forest, suggests that other factors act as barriers to forest transition in Misiones. Even at the department level, the forest transition model is not clearly supported. Of the 10 departments that lost rural population between 1990 and 2001, only five departments had an increase in natural forest and/or plantation cover, and in all cases, the increase was $<100 \mathrm{~km}^{2}$. It is commonly thought that poor rural inhabitants and subsistence agriculture are barriers for forest transition. In Misiones, the opposite appears to be the case. The mixed land-use class indicating subsistence agriculture declined from $4962 \mathrm{~km}^{2}$ in 1979 to 3505 $\mathrm{km}^{2}$ in 2006 (Fig. 4). Furthermore, areas that were classified as mixed use in $1987 / 1989$ were the major source of new forest in 2006 (Table 3). We think that the lack of concordance with the forest 
Table 3. Land-use transition matrix for the period of 1989-2006. Rows represent the source land-use category in 1987/1989 (top) and the status of the areas in 2006 (bottom). Columns represent the fate landuse categories in 2006 (left) and the status of the areas in 1987/1989 (right).

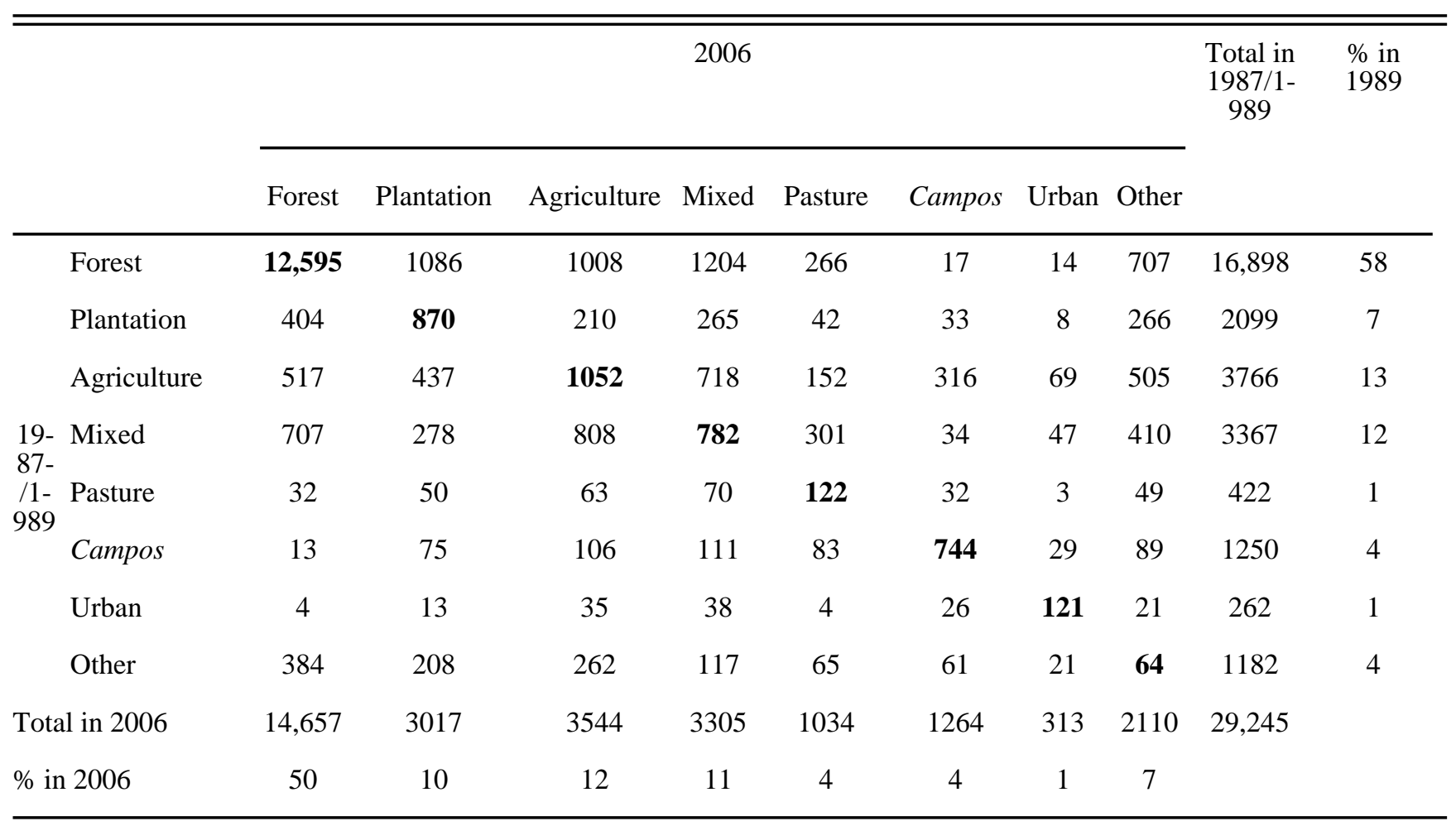

transition model is because even though there has been rural-urban migration, the productive lands containing agriculture and plantations have not been abandoned. The decrease in the number of farms and the increase in the mean size of the properties (Instituto Nacional de Estadísticas y Censos 1988, 2002) suggests that many smaller single-family operations have been transferred to a single owner. Although the rolling hills and soils are not as productive for large-scale activities as are other areas in Argentina, e.g., cattle production in the Pampas or soybean production in dry forest, the soils are sufficiently productive to make agricultural and forestry activities economically feasible in Misiones.

The increase in plantations from approximately 1 to $10 \%$ of the province during the last 33 years is, in part, the result of a government forest policy that subsidized this activity. In terms of land-use change, the greatest effect of this policy was the loss of natural forest. Between 1973 and 2006, $1803 \mathrm{~km}^{2}$ of forest was converted to plantation. Many plantations were also established in areas that were formerly classified as mixed use $\left(1848 \mathrm{~km}^{2}\right)$ or agricultural $\left(1654 \mathrm{~km}^{2}\right)$. A similar pattern of great increase in plantation was observed in Santa Catarina, Brazil (Baptista and Rudel 2006), where industrialization has promoted rural-urban migration, and policies and fiscal incentives have encouraged the establishment of plantations on abandoned agricultural lands. There has also been a rapid increase in plantations in campos grassland in Uruguay and in other regions of Argentina (Paruelo et al. 2006), similar to that observed in the southwestern departments of Misiones.

An increase in forest cover because of the establishment of plantations is a type of forest transition, but its contribution to environmental services can vary greatly (Rudel et al. 2005, Baptista and Rudel 2006). The low diversity and simple 
Fig. 5. Relationship between the change in mixed cover between 1989 and 2006 and the change in the rural population between 1991 and 2001 .

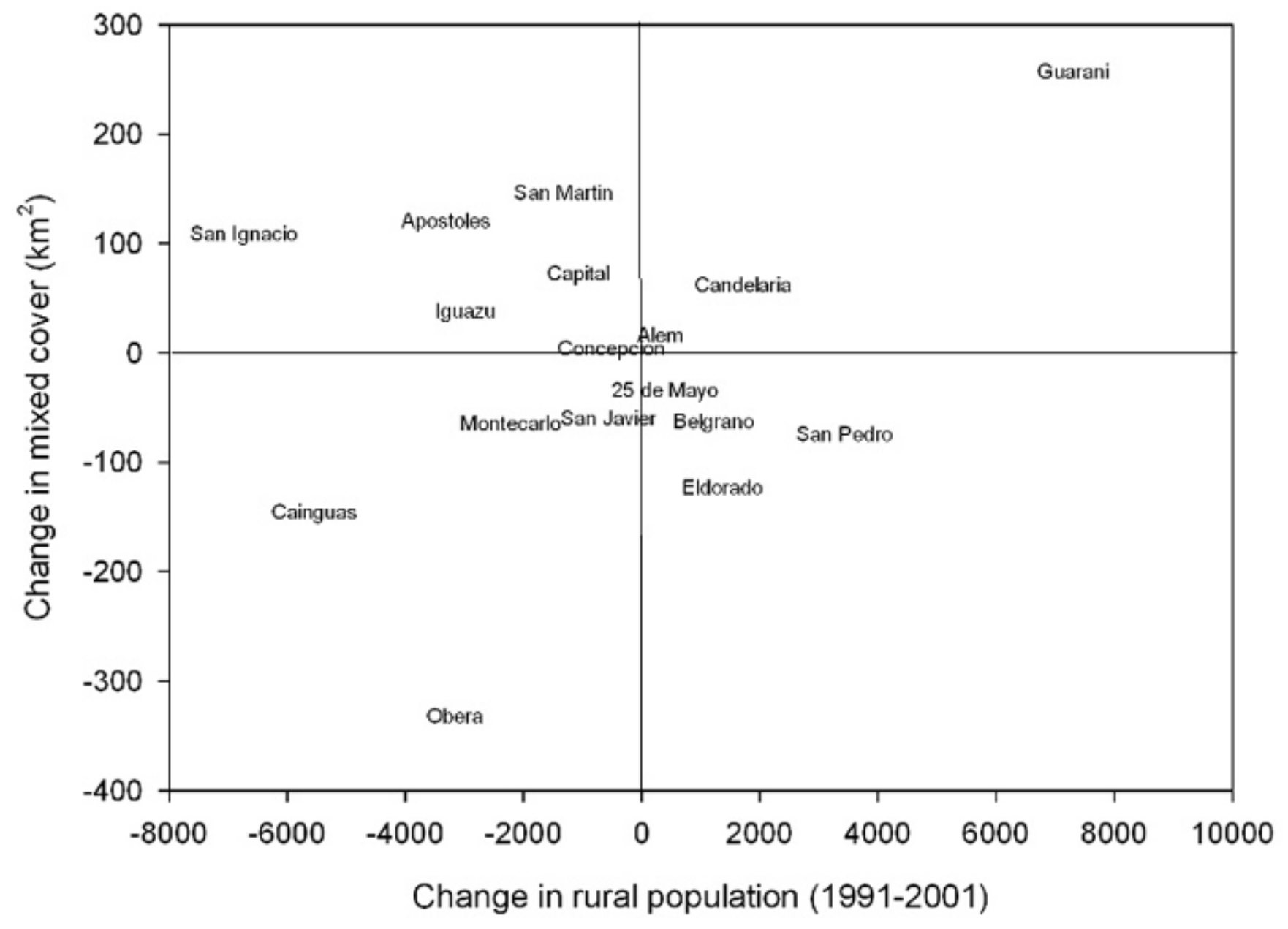

structure of commercial plantations can limit the use of these areas by forest-dependent species (Mardsen et al. 2001, Zurita et al. 2006), and some plantation species, e.g., Pinus spp., can invade adjacent forests (Richardson 1998). However, forest plantations can reduce soil erosion (Parrota et al. 1997), improve water quality (Kramer et al. 1997), increase carbon sequestration (Nilsson and Schopfhauser 1995), and provide habitat for many species (Spellerberg and Sawyer 1996, Lugo 1997). Furthermore, if plantations are not actively managed, they can act as a catalyst for secondary succession (Brown and
Lugo 1994, Lugo 1997). Clearly, management practices and the ecology of the individual species play large roles in determining the positive and negative effects of plantations on local biodiversity conservation.

Another important factor contributing to the lack of forest recovery is that Misiones is the major producer of yerba mate in Argentina, which is the most important perennial crop in the province (Manzi 2000). Other important crops in Misiones include tea and tobacco. The production of yerba 
Fig. 6. Relationship between the change in (A) forest and plantation cover and (B) native forest cover between 1989 and 2006 and the change in the rural population between 1991 and 2001.
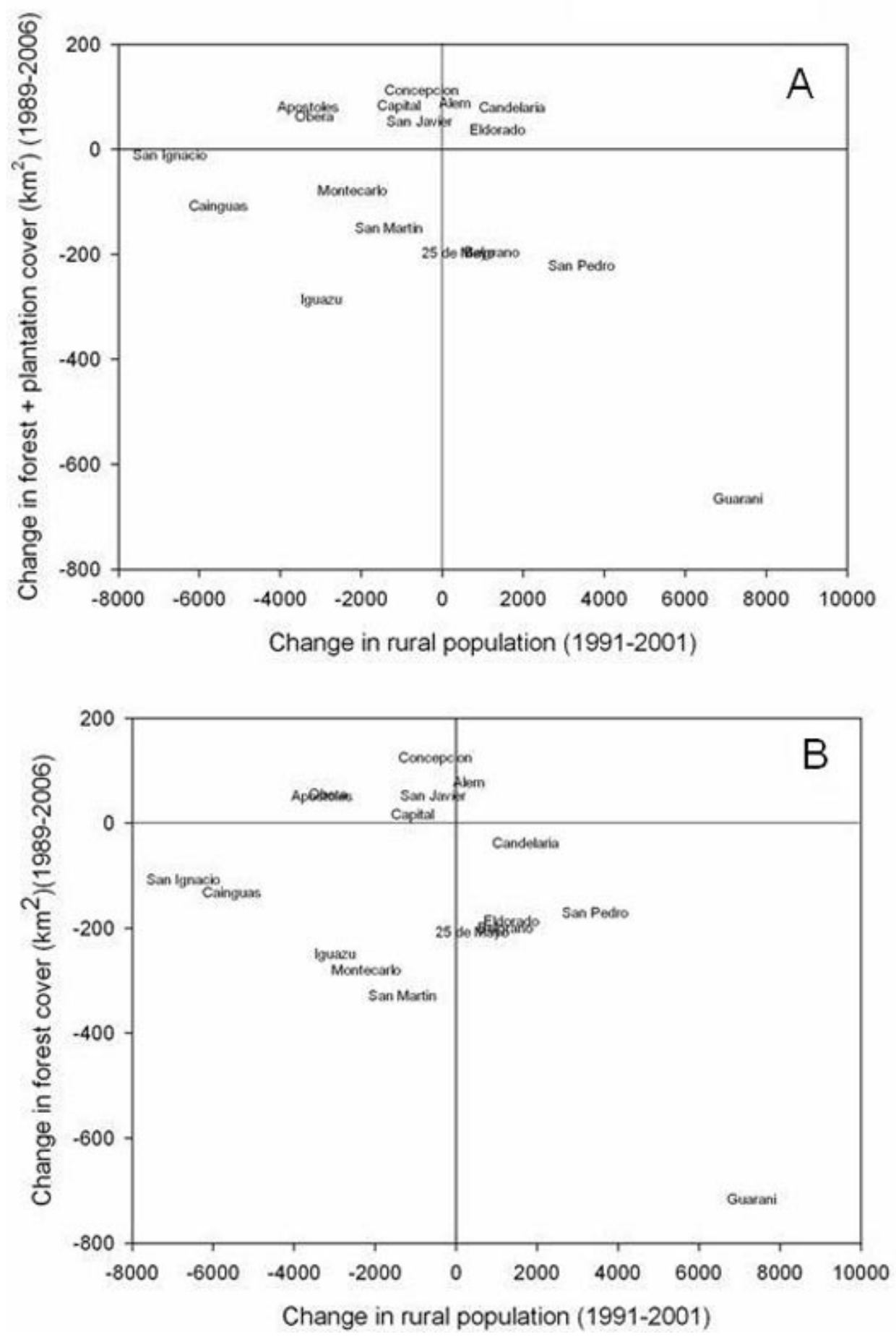
mate was initiated by the Jesuits in the 1700 s, and although production has varied greatly, in the late 1980s, the government established a research organization to provide technical assistance for the sector, resulting in the large increase in the agricultural land-use class between 1979 and 2006 (Fig 4). In the departments of Cainguas, Oberá, San Pedro, Guaraní, and Belgrano, the area of land in agriculture continued to increase during the period of 1989 to 2006.

Cattle ranching is another activity that could easily increase in scale. Within Misiones, cattle grazing occurs in campos in the southwestern departments and in pastures that have been established in previously forested areas mainly in the central and northern departments. During the study period, the major sources of new pasture were forest $\left(486 \mathrm{~km}^{2}\right)$ and areas of mixed use $\left(207 \mathrm{~km}^{2}\right)$, and although there was a slight decline between 1979 and 1987/1989, the overall trend was an increase in pasture. Furthermore, in Misiones, cattle ranching also occurs within forests, which involves the clearing of the understory to enhance grass productivity. Given the resolution of the images that we used, these areas would most likely be classified as forest; therefore, we have underestimated the effects of cattle ranching activities. The extent of cattle pastures is likely to increase given new government credits (i.e., Plan Ganadero) that promote an increase in cattle production from $2.5 \times 10^{5}$ head in 2000 to $1.0 \times 10^{6}$ head by 2010 .

The logging of natural forest is another important activity in Misiones that has important implications for conservation, but its effects may have been greatly underestimated. For example, selective logging can greatly change the structure and composition of native forest and enhance the invasion of species such as Chusquea ramosissima that can reduce local diversity and delay forest recovery (Placci and Di Bitetti 2006, Campanello et al. 2007). However, most of these areas would also continue to be classified as forest.

\section{What is stopping forest transition?}

The slowing of human population growth and increasing urbanization are trends that could reduce the rates of tropical deforestation and even result in forest recovery (Aide and Grau 2004, Wright and Muller-Landau 2006), but this is not occurring in Misiones. Although the population growth rate is slowing (Instituto Nacional de Estadísticas y Censos 2005) and the rural population is declining, forest cover continues to decline. In Misiones, local environmental, economic, and political factors appear to be barriers delaying forest transition. The most important factor appears to be the combination of relatively productive soils and government subsides, which has resulted in an increase in perennial crops, cattle production, and plantations of exotic species. The important differences between Misiones and other areas in Latin America where forest transition has been observed (e.g., Puerto Rico, Grau et al. 2003; Dominican Republic, Grau et al. 2007b; and Brazil, Perz and Skole 2003) are soil fertility and economic alternatives. As long as soils are relatively fertile and there are no other major barriers to large-scale agriculture such as steep slopes, agricultural activities will continue even if an area experiences rural-urban migration. In the adjacent regions of Brazil and Paraguay, there is no sign of forest transition; on the contrary, extensive areas of Atlantic Forest have been converted to cotton, sugar, and soybean cultivation (Galindo-Leal and Gusmão Câmara 2003). These areas have a much longer history of agriculture compared to Misiones, which is why the largest remnant of Atlantic Forest remains in Misiones. Nevertheless, if the government continues to promote the expansion of agriculture, cattle grazing, and forestry activities through subsides and other government support, the area of Atlantic Forest will continue to decline.

\section{Conservation and development implications}

The interactions between the demographic and landuse dynamics of Misiones described here can help to improve conservation and development activities within the province. Specifically, this information could be the basis for the formulation of future conservation and development scenarios for Misiones. For example, a positive scenario should include continued economic development in Misiones without further negatively affecting natural forest cover. We provide some recommendations that could help Misiones and many regions throughout the developing world to realize this scenario.

1. Diversify the provincial economy and improve urban social services. Although there has been an important increase in tourism in the last few years (e.g., $>1.0 \times 10^{6}$ 
visitors to Iguazu Falls in 2007), the economy of Misiones depends heavily on timber, agriculture, and cattle production. Throughout the world, rural-urban migration is one of the most important demographic dynamics. The influx of rural migrants can provide new workers for the manufacturing and service sectors, but these migrants need access to affordable education, housing, and health services if they are to improve their standard of living and contribute to a diversified economy. This demographic and economic transition has resulted in forest transition in many developed countries, and there are signs that it is beginning to occur in developing countries as well (Aide and Grau 2004);

2. Improve regional planning. The development and conservation needs of the province could be better balanced if there were an effort to:

- Concentrate agricultural and forestry activities in areas that have already been deforested. If the extensive areas that have been deforested for mixed use and pastures were used more efficiently for agricultural and forestry activities, this could increase productivity without impacting the remaining areas of native forest;

- Promote the establishment of protected areas in critical regions and local strategies of sustainable use alternatives in areas where the rural population continues to grow. Approximately $50 \%$ of Misiones is still covered with forest in different degrees of degradation, including $>7.0 \times 10^{5}$ ha of protected areas http://www.misiones.gov.ar/e cologia/), but new protected areas should be established between protected areas to prevent their isolation, e.g., between Yaboti Biosphere Reserve and the Iguazú-Uruguaí reserves in the north, or in habitats that are not presently protected, e.g., Araucaria forests and campos (see Giraudo et al. 2003). Most importantly, the largest areas of remnant forest are located in the departments where the rural population is still increasing; therefore, it is important to provide economically viable alternatives for these people who depend primarily on deforestation and subsistence agriculture. How these people use forest resources will have a major impact on the future of the Atlantic Forest of Misiones.
Responses to this article can be read online at: http://www.ecologyandsociety.org/voll3/iss2/art3/responses/

\section{Acknowledgments:}

This study was funded by grants from The Rufford Maurice Laing Foundation, the Russell Train Education for Nature Program of World Wildlife Fund, and the University of Puerto Rico (FIPI Program), and the National Science Foundation (\#DEB-0709598). Additional funding was provided by the National Science Foundation (\#DEB-0731594) for costs related to the symposium at the ATBC meeting in Morelia, Mexico, and the publication costs of the special issue. Satellite images were obtained from the Global Land Cover Facility of Maryland University (http://glcfapp.umiacs.umd. edu:8080/esdi/index.jsp), the Instituto de Pesquisas Espaciales of Brazil (www.dgi.inpe.br), the Fundación Vida Silvestre Argentina, and Delegación NEA of the National Parks Administration. We thank Sandra Baptista, Ricardo Grau, Mario Di Bitetti, and two anonymous reviewers for their comments. We also thank M. Pinazo and L. Paolini for their help with the GIS work.

\section{LITERATURE CITED}

Aide, T. M., and H. R. Grau. 2004. Globalization, migration, and Latin American ecosystems. Science 305:1915-1916.

Baptista, S. R., and T. K. Rudel. 2006. A reemerging Atlantic Forest? Urbanization, industrialization and the forest transition in Santa Catarina, southern Brazil. Environmental Conservation 33:195-202.

Belasteguí, H. M. 2004. Los colonos de Misiones. Universidad Nacional de Misiones, Posadas, Argentina.

Boserup, E. 1965. The conditions of agricultural growth: the economics of agrarian change under population pressure. Aldine Publishing, Chicago, USA. 
Brown, S., and A. E. Lugo. 1994. Rehabilitation of tropical lands: a key to sustaining development. Restoration Ecology 2(2):97-111.

Campanello, P. I., M. G. Gatti, A. Ares, L. Montti, and G. Goldstein. 2007. Tree regeneration and microclimate in a liana and bamboo-dominated semideciduous Atlantic Forest. Forest Ecology and Management 252(1-3):108-117.

Dobson, A.P.,A. D. Bradshaw, and A. J. M. Baker. 1997. Hopes for the future: restoration ecology and conservation biology. Science 277:515-525.

Fan, C. C. 2005. Interprovincial migration, population redistribution, and regional development in China: 1990 and 2000 census comparisons. Professional Geographer 57(2):295-311.

Galindo-Leal, C., and I. Gusmão Câmara, editors. 2003. The Atlantic Forest of South America: biodiversity status, threats and outlook. Island Press, Washington, D.C., USA.

Giraudo, A. R., E. R. Krauczuk, V. Arzamendia, and H. Povedano. 2003. Critical analysis of protected areas in the Atlantic Forest of Argentina. Pages 245-261 in C. Galindo-Leal and I. Gusmão Câmara, editors. The Atlantic Forest of South America: biodiversity status, threats and outlook. Island Press, Washington, D.C., USA.

Grau, H. R., and T. M.Aide. 2007. Are rural-urban migration and sustainable development compatible in mountain systems? Mountain Research and Development 27:119-123.

Grau, H. R., T. M. Aide, J. K. Zimmerman, J. R. Thomlinson, E. Helmer, and X. Zou. 2003. The ecological consequences of socioeconomic and land-use changes in post-agriculture Puerto Rico. Bioscience 53(12):1159-1168.

Grau, H. R., N. I. Gasparri, M. Morales, A. Grau, E. Aráoz, J. Carrilla, and J. Gutiérrez. 2007a. Regeneración ambiental en el noroeste argentino: oportunidades para la conservación y regeneración de ecosistemas. Ciencia Hoy 17(100):46-60.

Grau, H. R., M. Pérez, S. Martinuzzi, X. Encarnación, and T. M. Aide. 2007b. Cambios socioeconómicos y regeneración del bosque en la República Dominicana. Pages 211-227 in M. González-Espinosa, J. M. Rey-Benayas, and N.
Ramírez-Marcial, editors. Restauración de bosques en América Latina. Fundación Internacional para la Restauración de Ecosistemas (FIRE) y Editorial Mundi-Prensa México, Distrito Federal, Mexico.

Guerrero Borges, V. 2004. Uso del suelo y transformación del paisaje en Colonia Andresito, Misiones. Technical Report. Fundación Vida Silvestre Argentina, Buenos Aires, Argentina.

Instituto Nacional de Estadísticas y Censos. 1970. Censo nacional de población y vivienda 1970. Instituto Nacional de Estadísticas y Censos, Buenos Aires, Argentina.

Instituto Nacional de Estadísticas y Censos. 1980. Censo nacional de población y vivienda 1980. Serie D: población. Instituto Nacional de Estadísticas y Censos, Buenos Aires, Argentina.

Instituto Nacional de Estadísticas y Censos. 1988. Censo nacional agropecuario 1988. Instituto Nacional de Estadísticas y Censos, Buenos Aires, Argentina.

Instituto Nacional de Estadísticas y Censos. 1991. Censo nacional de población y vivienda 1991. Instituto Nacional de Estadísticas y Censos, Buenos Aires, Argentina.

Instituto Nacional de Estadísticas y Censos. 2001. Censo nacional de población y vivienda 2001. Instituto Nacional de Estadísticas y Censos, Buenos Aires, Argentina. Available online at: http://www.i ndec.mecon.ar/webcenso/index.asp.

Instituto Nacional de Estadísticas y Censos. 2002. Censo nacional agropecuario 2002. Instituto Nacional de Estadísticas y Censos, Buenos Aires, Argentina.

Instituto Nacional de Estadísticas y Censos. 2005. Proyecciones provinciales de población por sexo y grupo de edad. 2001-2015. Serie análisis demográfico 31. Instituto Nacional de Estadísticas y Censos, Buenos Aires, Argentina.

International Organization for Migration. 2004. IOM strategy: current and future migration realities and IOM's role. CRP/12. Eighty-eighth session of the Council. International Organization for Migration, Geneva, Switzerland. Available online at: http://www.old.iom.int//DOCUMENTS/ GOVERNING/EN/MC INF 274.PDF. 
Klooster, D. 2003. Forest transitions in Mexico: institutions and forests in a globalized countryside. Professional Geographer 55:227-237.

Kramer, R. A., D. D. Richter, S. Pattanayak, and N. P. Sharma. 1997. Ecological and economic analysis of watershed protection in eastern Madagascar. Journal of Environmental Management 49 (3):277-295.

Laclau, P. 1994. La conservación de los recursos naturales y el hombre en la Selva Paranaense. Technical Bulletin Number 2. Fundación Vida Silvestre Argentina, Buenos Aires, Argentina.

Lugo, A. E. 1997. The apparent paradox of reestablishing species richness on degraded lands with tree monocultures. Forest Ecology and Management 99(1-2):9-19.

Lutz, W., W. Sanderson, and S. Scherbov. 2001. The end of world population growth. Nature $\mathbf{4 1 2}$ (6846):543-545.

Malthus, T. R. 1798. An essay on the principle of population as it affects the future improvement of society, with remarks on the speculations of $\mathrm{Mr}$. Godwin, M. Condorcet, and other writers. J. Johnson, London, UK. Available online at: http://w ww.econlib.org/library/Malthus/malPop.html.

Manzi, G. A. 2000. Desarrollo industrial de Misiones. Una óptica crítica para la discusión con miras a la integración territorial. Universidad Nacional de Misiones, Posadas, Argentina.

Mardsen, S. J., M. Whiffin, and M. Galetti. 2001. Bird diversity and abundance in forest fragments and Eucalyptus plantations around an Atlantic forest reserve, Brazil. Biodiversity and Conservation 10 (5):737-751.

Martínez Sarasola, C. 1992. Nuestros paisanos los indios. Emecé, Buenos Aires, Argentina.

Mather, A. S., and C. L. Needle. 1998. The forest transition: a theoretical basis. Area 30(2):117-124.

Myers, N., R. A. Mittermeier, C. G. Mittermeier, G. A. B. da Fonseca, and J. Kent. 2000. Biodiversity hotspots for conservation priorities. Nature 403(6772):835-858.
Nilsson, S., and W. Schopfhauser. 1995. The carbon-sequestration potential of a global afforestation program. Climatic Change 30 (3):267-293.

Parés-Ramos, I. K., W. A. Gould, and T. M. Aide. 2008. Agricultural abandonment, suburban growth, and forest expansion in Puerto Rico between 1991 and 2000. Ecology and Society 13(2): 1. [online] URL: http://www.ecologyandsociety.org/vol13/iss2/ art1/.

Parrota, J. A., J. W. Turnbull, and N. Jones. 1997. Catalyzing native forest regeneration on degraded tropical lands. Forest Ecology and Management 99 (1-2):1-7.

Paruelo, J. M., J. P. Guerschman, G, Piñeiro, E. G. Jobbágy, S. R. Verón, G. Baldi, and S. Baeza. 2006. Cambios en el uso de la tierra en Argentina y Uruguay: marcos conceptuales para su análisis. Agrociencia 10(2):47-61. Available online at: $\mathrm{ww}$ w.fagro.edu.uy/agrociencia/VOL10/2/pp47-61.pdf

Perz, S. G., and D. L. Skole. 2003. Secondary forest expansion in the Brazilian Amazon and the refinement of forest transition theory. Society and Natural Resources 16(4):277-294.

Pimentel, D., M. Tort, L. D'Anna, A. Krawic, J. Berger, J. Rossman, F. Mugo, N. Doon, M. Shriberg, E. Howard, S. Lee, and J. Talbot. 1998. Ecology of increasing disease: population growth and environmental degradation. BioScience $\mathbf{4 8}$ (10):817-826.

Placci, G., and M. Di Bitetti. 2006. Situación ambiental en la ecorregión del Bosque Atlántico del Alto Paraná (Selva Paranaense). Pages 197-209 in A. Brown, U. Martínez Ortiz, M. Acerbi, and J. Corcuera, editors. La situación ambiental Argentina 2005. Fundación Vida Silvestre Argentina, Buenos Aires, Argentina.

Preston, D. 1996. People on the move: migrations past and present. Pages 165-187 in D. Preston, editor. Latin American development: geographical perspectives. Second edition. Harlow, Essex, UK.

Richardson, D. M. 1998. Forestry trees as invasive aliens. Conservation Biology 12(1):18-26. 
Rudel, T. K., D. Bates, and R. Machinguiashi. 2002. A tropical forest transition? Agricultural change, outmigration, and secondary forests in the Ecuadorian Amazon. Annals of the Association of American Geographers 92:87-102.

Rudel, T. K., O. T. Coomes, E. Moran, F. Achard, A. Angelsen, J. Xu, and E. Lambin. 2005. Forest transitions: towards a global understanding of land use change. Global Environmental Change 15 (1):23-31.

Sanderson, E. W., M. Jaiteh, M. A. Levy, K. H. Redford, A. V. Wannebo, and G. Woolmer. 2002. The human footprint and the last of the wild. Bioscience 52(10):891-904.

Schiavoni, G. 1995. Colonos y ocupantes: parentesco, reciprocidad y diferenciación social en la frontera agraria de Misiones. Universidad Nacional de Misiones, Posadas, Argentina.

Song, C., C. E. Woodcock, K. C. Seto, M. P. Lenney, and S. A. Macomber. 2001. Classification and change detection using Landsat TM data: when and how to correct atmospheric effects? Remote Sensing of Environment 75(2):230-244.

Southworth, J., and C. Tucker. 2001. The influence of accessibility, local institutions and socioeconomic factors on forest cover change in the mountains of western Honduras. Mountain Research and Development 21(3):276-283.

Spellerberg, I. F., and J. W. D. Sawyer. 1996. Standards for biodiversity: a proposal based on biodiversity standards for forest plantations. Biodiversity and Conservation 5(4):447-459.

United Nations Population Fund. 2007. State of world population 2007: unleashing the potential of urban growth. United Nations Population Fund, New York, New York, USA. [online] URL: http:// www.unfpa.org/swp/2007/english/introduction.html

Vitousek, P. M., H. A. Mooney, J. Lubchenko, and J. M. Melillo. 1997. Human domination of Earth's ecosystems. Science 277:494-499.

Waggoner, P. E., and J. H. Ausubel. 2001. How much will feeding more and wealthier people encroach on forests? Population and Development Review 27(2):239-257.
Wright, S. J., and H. C. Muller-Landau. 2006. The future of tropical forest species. Biotropica $\mathbf{3 8}$ (3):287-301.

Zurita, G. A., N. Rey, D. M. Varela, M. Villagra, and M. I. Bellocq. 2006. Conversion of the Atlantic Forest into native and exotic tree plantations: effects on bird communities from the local and regional perspectives. Forest Ecology and Management 235 (1-3):164-173.

Zweifler, M. O., M. A. Gold, and R. N. Thomas. 1994. Land use evolution in hill regions of the Dominican Republic. Professional Geographer 46:39-53. 